\title{
Customer satisfaction in the digital era: evidence from Islamic banking
}

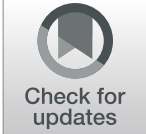

\author{
Ghazi Zouari (1) and Marwa Abdelhedi
}

\author{
* Correspondence: zouarighazi@ \\ yahoo.fr \\ Faculty of Economic Sciences and \\ Management, University of Sfax, \\ Sfax, Tunisia
}

\begin{abstract}
Purpose: Based upon an extended SERVQUAL model, this paper attempts to contribute to the Islamic banking literature by examining the impact of digitalization, as a service quality dimension, on customer satisfaction.

Design/methodology/approach: Two dimensions, i.e., digitalization and compliance, are added to the existing SERVQUAL model of five dimensions. Results are drawn from a self-completed survey of a convenience sample of 145 Tunisian Islamic bank customers for the year 2018. Factor analysis and regression analysis are used to determine factor structure and determine the impact of service quality dimensions, especially digitalization, on customer satisfaction in Islamic banking.
\end{abstract}

Findings: The factor analysis extracted five dimensions of service quality, i.e., confidence, compliance, digitalization, tangibles, and human skills. The paper demonstrates a positive and significant relationship between the main dimensions of customer service quality and customer satisfaction, except for tangibles.

Research limitations/implications: Although the outcomes lend support to the extended SERVQUAL model, the results are derived based on a relatively average sample size in one country (Tunisia). It might also be useful to enlarge the study sample for better generalization of the findings in other countries and include a comparison between Islamic versus conventional banking about service quality and customer satisfaction. Moreover, we can applicate another original method for the Measuring and Implementing Service Quality like the multicriteria method dubbed (MUSA).

Managerial implications: To remain competitive, Tunisian Islamic banks need to pay attention to the way the services are delivered and not take it for granted that customers are only focusing on compliance. Dealing henceforth with Generation $Y$ customers, they must persevere in bringing their customer service into the digital era.

Originality/value: This study is one of the few which tries to investigate the drivers of customer satisfaction for Islamic banks in a Digital Era. It reveals that although customers pay special attention to Sharia laws, the way services are delivered matters to them too. From now on, digital banking must appear among the Islamic bank features to stay relevant in the Digital Era.

Keywords: Service quality, SERVQUAL model, Customer satisfaction, Digital banking, (Continued on next page) 
(Continued from previous page)

Islamic banks, Tunisia

JEL classification: $\mathrm{G} 21, \mathrm{O} 33$

\section{Introduction}

Across the globe, digital technologies are mushrooming in all areas, including the banking sector (Ganguli \& Roy, 2011). Especially, newly developed and implemented technologies are changing people's lifestyle and consumption habits which impacts considerably the nature of companies-customers relationships. This is due to the evolution of the expectations of today's tech-savvy digital consumers who are looking forward to the delivery of digital solutions by their banks (Sreejesh, Anusree, \& Mitra, 2016).

The digital transformation in the banking sector is likely to continue and further ramp up given the specifics of the post-crisis market environment. Competing from now on in the digital era, banks are called to greater integration of digital technologies in response to market changes and customers' needs. Moreover, they must persevere into accumulating digital capabilities to take their customer service into the next level, allowing so to enhance customer satisfaction rates and make higher profits (Reichheld \& Sasser Jr., 1990) at the same time as ensuring effective automation and related cost efficiency (Alstad, 2002).

A dynamic segment that is emerging in the banking sector is Islamic banking. Thanks to the relatively resilient performance of this sector during the most serious financial crisis ever seen, Islamic finance has witnessed remarkable development around the world. Nevertheless, this is not the case in North African countries. The factors that account for this underdevelopment were summarized by Wilson (2011) as follows: firstly, the limited development of retail banking generally, second the lack of consumer awareness about Islamic banking, and third, the low scale of government support. In Tunisian banking, the Islamic banking sector remains embryonic and struggles to gain market share (Boulila \& Ben Slama, 2014). The current Islamic banking system comprises four Islamic banks. The first one is "Al Baraka Bank Tunisia" licensed to offer Islamic banking as an offshore institution since 1983. The second is a regional office of the United Arab Emirates (UAE)-based Islamic bank "Noor Islamic Bank" established in June 2008. The third and the most expanded one is "Zitouna Bank" launched in May 2010 by the son in law of the deposed president. The last one is "El Wifak Bank" launched in May 2017. However, there is a sustainable development scope for Islamic banking given the relevant political changes in post-revolution Tunisia and the presence of market push (Gallup, 2014), and hence, Tunisian Islamic banks need to take advantage of opportunities associated with the development of the Islamic financial landscape in Tunisia.

Although the whole notion of Islamic banking hints at the fulfillment of religious obligations of pious Muslim customers, Tunisian Islamic banks should not take it for granted that customers are only focusing on compliance and must be more conscious about the service quality evaluation according to customers' expectations given the fact that service quality is closely related to customer satisfaction in Islamic banking (Janahi \& Almubarak, 2017). Most banks are on the path to digital adoption to fulfill the ever- 
increasing needs of the digital generation; however, Islamic banking constitutes a particular banking segment to which conventional marketing rules do not necessarily apply (Muslim, Zaidi, \& Rodrigue, 2013).

So, does the digital transformation phenomenon have any impact on the major service evaluation criteria for Tunisian Islamic banking? And what should be the potential benefits of a customer service digitalization process concerning customer satisfaction in Islamic banking?

The underpinning theme of this study is that the underlying religious philosophy of Islamic finance can no longer be the only source of competitiveness, but that a marketing strategy of ongoing service quality improvement in light of market changes is even more necessary for banks to remain competitive. Given the above, the elaboration of an adapted measurement model of service quality with consideration for new consumption habits seems to be more prominent than ever to enhance service offerings and meet digital consumers' expectations with the ultimate goal of reaching high levels of customer satisfaction.

This paper looks at the importance of integrating digitization and compliance into consumers' satisfaction dimensions for the Islamic banking context. To do that, a review of the literature is presented hereafter. The section that follows looks at the methodology and reports on data collection, analysis, and results. The discussion of the findings and subsequent implications are then provided. The final part of the paper draws the concluding remarks and sums up the limitations of the study.

\section{Literature review}

\section{Customer satisfaction and service quality}

Customer satisfaction is what a consumer feels about a particular service or product after it has been used (Solomon, 1996). It would be considered as one of the primary strategic goals to which every organization shall pay particular attention (Dabholkar, Thorpe, \& Rentz, 1996). That is because almost all studies show a tight connection between customer satisfaction and repurchase intentions, positive word of mouth (Dispensa, 1997), market reputation, and customer loyalty (Cronin \& Taylor, 1992) leading so to profit increase and cost reduction (Cooil, Keiningham, Aksoy, \& Hsu, 2007; Kumar \& Reinartz, 2006). Now, the first thing that came in mind when dealing with customer satisfaction is service quality since satisfaction is particularly sensitive to the level of service quality provided by the organization. It is suggested that service quality is an underlying determinant of customer satisfaction (Yavas, Bigin, \& Shenwell, 1997); hence, it is important for management to find a concise definition of service quality and search for the most reliable assessment process to ensure high-quality service offerings.

Service quality is defined by Gronroos (1983) as the fact of meeting what one company's customers expect from its service offerings while it represents the gap which may exist between what customers expected to get as service and service quality as perceived by them (Parasuraman, Zeithaml, \& Berry, 1988). Although providing a meaningful measurement tool is essential for service quality management, it is often hard to measure the quality of service due to certain inherent characteristics including heterogeneity, intangibility, perishability, and inseparability (Hoffman \& Bateson, 2001). 
The increasing awareness about the key role of both the concepts of quality and satisfaction in a constantly changing banking market have made of them the focus of a multitude of studies Throughout the body of academic literature, scholars continually refer to Parasuraman, Zeithaml, and Berry's (1985, 1991); Parasuraman et al.'s (1988) original work. Through numerous qualitative researches, these authors concluded that customers provide a congruous evaluation of service quality regardless of the service industry and then conceived a five-dimension measure scale of service quality and provided concise definitions for each of these dimensions.

- Reliability: the ability to be trusted because of performing the promised with precision

- Tangibles: the tangible aspects associated with the service like the appearance of employees, physical facilities, and equipment

- Responsiveness: the willingness of staff to react to customers quickly and positively

- Assurance: the knowledge and courtesy of employees and their ability to convey trust, faith, and confidence among customers

- Empathy: the caring and individual attention provided for customers.

Careful empirical testing of the theorized service quality dimensions has led to the recognition of a 22-item scale named SERVice QUAlity (SERVQUAL, Parasuraman et al., 1991). The basic assumption underlying the SERVQUAL model is that service quality is interpreted in terms of the gaps which may exist between what customers expected to get as service and service quality as perceived by them. Thus, a low-quality service corresponds to that case in which customers' expectations are greater than their perceptions while exceeding expectations implies that service quality is deemed high. Since its conception in 1988, SERVQUAL has gained high attention and has been applied in a multitude of service industries, including the banking industry (e.g., Veysel, Erkan, \& Hüseyin, 2018). Nevertheless, the model faced a wide criticism, mainly directed at its conceptual appropriateness, its operationalization, and the ambiguity of the expectations construct (Buttle, 1996). Moreover, empirical evidence does not support the dimensional stability of SERVQUAL, the five-dimensional concept of service quality does not hold up when the research is replicated in different contexts (Babakus \& Boller, 1992), and the 22 defined items do not load on to the corresponding dimensions regularly (e.g., Carman, 1990). Consequently, there may not be a relevant and universal

measure of service quality for service industries. Indeed, the relative importance of these dimensions differs from one country to another as well as the demographic characteristics and cultural background of customers. Despite these criticisms, it is recognized that the SERVQUAL measurement tool represents a generic instrument that enables a meaningful assessment for service quality in terms of assurance, reliability, tangibles, empathy, and responsiveness (Saleem, Zahra, Ahmad, \& Ismail, 2016).

\section{Customer satisfaction and service quality in Islamic banking}

Service quality is more likely to gain weight in the banking industry given the constantly changing banking environment. The highly competitive financial market is pushing the banks, including Islamic banks, to constantly rethink their service offerings 
in light of the evolving customers' expectations for service quality aspects. Together with conventional banks, Islamic banks aim to meet customers' banking needs. The main difference between them is mere that Islamic banking conducts its operation based on the principles and teachings of Islam known as Islamic law (Shariah).

Islamic banking transactions are carried out following the rules, regulations of Islamic Shariah, known as fiqh muamalat (Islamic rules on transactions). There is no place for interest receipts and payments, excessive uncertainty (gharar), gambling, speculations, and illegitimate transactions in the Islamic financial system (Khan, 2010). It is a complete set of the financial framework based on discipline and promotes the level of fairness and equity in the carrying out of the banking business. However, Profits and Loss Sharing (PLS) remains the feature most emphasized by Islamic banking advocates (Zaher \& Hassan, 2001). The ban of interest-based financial transactions in Islamic religion and the aspiration of pious Muslims to making a practical reality of their religious values has made from Islamic banking a key player in global financial circles over the past four decades.

Customer service is a major organizational process that companies should optimize to enhance customer satisfaction rates, reach a wider market, and increase earnings (Jahanshahi, Gashti, Mirdamadi, Nawaser, \& Khaksar, 2011). So, roughly speaking, a large number of the studies analyzing the relationship between service quality and customer satisfaction within Islamic banking have adopted the original SERVQUAL tool as it was conceived by its authors and some of them have used an adjusted version of it. Abdullah and Kassim (2009) explored the dimensional structure of banking services offered by Qatari Islamic banks.

They defined a set of four quality dimensions that are tangibles, human skills, online banking, and empathy. However, they noted that only two dimensions that are empathy and human skills were significant when examining customer satisfaction. Al-Tamimi and Al-Amiri (2003) studied the service quality pattern of UAE Islamic banks else.

One of the contributions of the study is the confirmation of the validity of SERVQUAL for Islamic banks, at least for their sample. They also realized that empathy and tangibles were the most important dimensions. In another distinctive study, Amin and Isa (2008) focused on the association between service quality as perceived by Malaysian customers and their satisfaction level with Islamic banks using an adjusted SERVQUAL model consisting of six dimensions. They added a new dimension under service quality dimensions which they called "compliance" given the foundation philosophy underlying Islamic banking. In conclusion, the researchers suggested that that the standard pattern of Islamic banking service quality should consist of the six dimensions and that the quality of Islamic banks service offerings was correlated with their customers' satisfaction scores. Furthermore, it is important to highlight the exceptional work of Owen and Othman (2001) who suggested a new service quality assessment tool for Islamic banks which they called CARTER (Compliance, Assurance, Reliability, Tangibles, Empathy, Responsiveness). The novel set of service quality was defined based on a customized Parasuraman et al.'s $(1985,1988,1991)$ five dimensions to suit Islamic banking industry specificities. Yet, a new dimension named "Compliance with Islamic law" had to be included in the existent five-dimensional concept that refers to the ability of the Islamic bank to fulfill with Islamic law and 
operate under the Islamic banking principles. This dimension includes such items as "Run on Islamic law and principles," "no interest rates are applicable for neither loans nor savings," "provision of Islamic products and services," "provision of free interest loans," and "provision of PLS-based products." The study of Owen and Othman has probably some uniqueness despite the handicap of the model's validity (Hafsa, 2013). The problem derives mainly from the sample which took part in this study because it had to represent the clients of only one bank. Later on, some researchers like Osman, Ali, Zainuddin, Rashid, and Jusoff (2009) and Janahi and Almubarak (2017) opted for the testing of the CARTER's validity in different Islamic banks from other regions.

\section{Customer satisfaction and service quality in the digital era}

Over time, and due to the digital revolution, society is being confronted with an unprecedented shift away from an industrial to a digital orientation. A new customer generation who grew with Internet democratization is more prone to technological developments. Consequently, the digital transformation has become an obligation rather than a choice for today's organizations, banks are not excepted given the breakthrough development in fintech solutions. Financial technology, often shortened to Fintech, has become a widely used term today which refers to the adoption of new technologies by the financial service institutions, especially banking institutions. However, by further examining the history of banking activity development, it appears that this is not a brand-new concept. The banking sector is seen as the vanguard sector of the fintech-based service revolution (Barras, 1990) so that the banking landscape has witnessed the development of a multitude of fintech innovations that includes Electronic Fund Transfer at the Point of Sale (EFTPOS), Automated Teller Machine (ATM), Internet banking, and mobile banking. Owing to ever-increasing competition within banking services, banks have embarked on the development of technologydriven strategies since empowering customers with technology-based service delivery systems generates cost-savings and improves operational efficiency (Alstad, 2002) and should boost customer satisfaction level, allowing to strengthen customer retention and generate further revenues (Reichheld \& Sasser Jr., 1990).

With more widespread internet penetration and mobile devices especially smartphones, the innovations became more intense from the 2000s onward which may be the starting point for the digital revolution. There is often a great difference between the era of the internet during the 1990s and the digital era at present. Digital has been dramatically reshaping the habits and preferences of consumers, whose lives are more and more involved with digital innovation, leading to a profound impact on the banking industry (Ganguli \& Roy, 2011). Nevertheless, the impact is not all negative for traditional banks. There are still considerable customer segments showing a preference for brick and mortar experience. However, over time, banks may face a considerable reduction in their customer base when digital natives, who have been immersed in technology their entire lives (Prensky, 2001), form the majority of the population unless the banking sector embraces digital transformation. That seems to be more relevant as previous studies show that differences do exist in acceptance and usage levels of technologies across customer segments depending on their beliefs about technology (Dabholker, 1996). 
Digitalization refers to the process in which the use of digital technology by an organization is adopted or increased (Castells, 2009). Regarding banking, that means acquiring technology-centric capabilities that enable new methods of interaction and service delivery to improve customer's experience. Owing to the technological evolution in the banking sector, we will probably witness another revolution in banks' marketing strategies (Dootson, Beatson, \& Drennan, 2016). Although digital banking is technology related, it is service-oriented and designed around the needs of digital natives that grew up with computers as a daily part of their lives and that are living in a broadly interconnected world. To reach a younger and more digitally savvy customer base, marketing efforts should hinge revolve around the offering of personalized services and digitally empowered experiences to enhance customer satisfaction since the latter is widely assumed and assessed to determine repeat sales, positive word of mouth recommendations, and mostly customer loyalty (Bearden \& Teel, 1983).

In most of the previously undertaken studies, it was suggested that service quality dimensions are the determinant criteria that influence the customers' decision over the choices in the banking selection. Nevertheless, Islamic banking constitutes a particular segment in which the traditional rules of marketing in the banking industry may not apply due to religious-based reasons. Religion is considered to be the most important bank selection factor (Metawa \& Almossawi, 1998). However, the evidence did not bear out the claim that Islamic banking reflects Islamic values, previous studies found that the selection of Islamic banks is not founded solely on the customers' religious beliefs (Dusuki \& Abdullah, 2006). Therefore, Islamic banks must persevere in working on the demand of, or response to its customers' needs and wants because it is obvious these factors that develop their perception of quality. The latte, however, is strongly influenced by customers' demographic characteristics (Urban \& Pratt, 2000), the development of a valid and distinct measure of service quality is even more vital to address customer needs in an increasingly digital world. Customers are already ahead of many banks in how they use digital technology to manage their financial lives, in fact, according to Ernst and Young (2016), 81\% of Gulf Cooperation Council (GCC) Islamic banking customers are expected to be ready to switch to the bank offering a greater digital experience. This shift towards digital banking means that banks' marketing management model is changing, making it crucial for Islamic banks to understand the impact of digital banking on customer satisfaction. Previous research has focused on the relationship that may exist between customer satisfaction and e-service quality within the banking sector (e.g., Isaac, 2011) and the factors influencing customers' acceptance of e-banking (e.g., Martins, Oliveira, \& Popovic, 2014), but digital banking should not be treated as a separate dimension among those which define and shape the service quality concept as pursued in this paper. Digital banking should not only be considered as a kind of service but also as a new feature that must exist among the essential features a bank must acquire.

In brief, overall satisfaction with a service arises from a complex and multidimensional process. Thus, developing service marketing theory requires an understanding of customers' needs to translate these into the delivery of services matching those needs. The research conducted by Parasuraman et al. $(1985,1988,1991)$ claimed that the developed theoretical model will successfully act as a basic template for the assessment of service quality. Nonetheless, this research was conducted 30 years ago. Thus, what 
may have constituted as significant previously may not be entirely relevant to today's customers.

Based on the explanations mentioned above and like several studies that have used an adjusted version by integrating compliance (Amin \& Isa, 2008; Owen \& Othman, 2001) or online banking (Abdullah \& Kassim, 2009), this study adopts an adjusted SERVQUAL model applicable to the Islamic banking sector as an instrument to measure customers' satisfaction. Indeed, the original version of Parasuraman et al. (1985, 1988, 1991) also considers two additional dimensions.

The first one, named "compliance," refers to the ability of the Islamic bank to comply with the rules and regulations of Islamic Shariah and operate under Islamic banking principles. According to Owen and Othman (2001), this dimension is the most important when assessing customer satisfaction of Islamic banks. In this context, several studies (Janahi \& Almubarak, 2017; Osman et al., 2009) confirm that this new dimension is essential in the study of the relationship between service quality and the level of customer satisfaction of Islamic banks.

The second one, called "digitalization" refers to the extent to which Islamic banks are embracing digital transformation. This factor is defined by variables such as the provision of online services, whether the bank offers electronic payment solutions, whether it is active in social media, and whether it provides mobile banking services and apps. Several authors (Abdullah \& Kassim, 2009; Isaac, 2011; Martins et al., 2014) show that the decision-making process for customers has changed with the proliferation of digital technologies and mobile phone devices. Competing in the digital age, Islamic banks must also take the real "digital train." They must therefore not only meet the religious needs of the Muslim community but above all understand the environment of their future customers and exploit technological advances to meet the evergrowing needs of the digital generation and create an atmosphere where they represent the bank "Most admired" that young people want to work with.

\section{Method}

\section{Measurement instrument}

A self-reporting questionnaire was designed to take account of previous research. The instrument contains three sections. The first section was designed to elicit demographic information of Tunisian Islamic banking customers. In the second one, the theoretical service quality dimensions as advanced by Parasuraman et al. (1988) were adjusted by integrating simultaneously two additional dimensions, compliance, and digitalization, to suit the research context. The original items were translated to French since this language is the most used in the business industry in Tunisia. A pre-test was then conducted with some Tunisian Islamic banks' customers, and minor modifications were made accordingly to ensure that the questions were not repetitive. A total of 28 items are used to capture respondent views about service quality. Moreover, the paper had to deal only with service quality perception to be more effective (Dabholkar et al., 1996). Respondents were invited to rate their answers on a five-Likert scale to improve response rate and avoid respondent fatigue (Herington \& Weaven, 2009). They were required to point out the level of service quality comprising of seven constructs with various statements ranging from strongly dissatisfied to strongly satisfy. The scale was 
taken from existing research of Naser, Jamal, and Al-Khatib (1999) and Akhtar, Hunjra, Syed Waqar Akbar, Ur-Rehman, and Niazi (2011) to measure satisfaction level of employees regarding the service quality provided by bank. Through the latter section, overall satisfaction is measured using a four-item measure identified based on previous studies (Manrai \& Manrai, 2007; Munusamy, Chelliah, \& Hor, 2010; Owen \& Othman, 2001). To ensure the validity of this research study, the respondents were required to respond to each question. SPSS was used for recording and statistical analysis part and linear regression was used to test the model (Akhtar et al., 2011; Fakhfakh, Zouari, \& Zouari-Hadiji, 2012; Zouari, 2008, 2011; Zouari-Hadiji, 2010).

\section{Sampling and data collection}

Data collection has been made based on an online questionnaire for the customers of the two leading Islamic banks in Tunisia "Zitouna" and "Al Baraka." The choice of the Tunisian context is justified by the fact that households and firms are increasingly interested in the services provided by Islamic banks especially after the Revolution of 2011. So, it is very useful to study the reality of Tunisian Islamic banks which have specificities compared to their counterparts in particular with the promulgation of the new banking law of 2016 recognizing for the first-time banks which apply Islamic law.

The sample which is composed of 145 respondents from all Tunisian governorates was chosen using the convenience sampling technique ${ }^{1}$. Based on the general guidelines by prior researchers on the sample size (Boomsma, 1985, Kerlinger, 1986 and MacCallum, Widaman, Zhang, and Hong (1999) ${ }^{2}$ and given the number of items used in this study (28 items), our sample of 145 respondents therefore meets the minimum requirements from the statistical perspective. We audited the reliability of the survey results based on the Cronbach alpha coefficient. All service quality dimensions, namely compliance, assurance, reliability, tangibles, empathy, responsiveness, and digitalization showed high reliability $(0.815,0.826$, $0.896,0.835,0.761,0.899$, and 0.825 , respectively, See Table 1). Moreover, alpha for the overall model had a high score (0.948). This result is obviously within the range accepted by Nunnally and Bernstein (1994), indicating the measure was robust.

Examination of demographic characteristics indicates that the percentage of male and female respondents is almost equally distributed among the surveyed Islamic bank customers ( $48 \%$ female, $52 \%$ male). The sample consisted mostly of young customers ( $83 \%$ aged between 20 and 38) because they have greater access to technology, and they are more likely to reflect digitally savvy customer needs.

\footnotetext{
${ }^{1}$ This is a non-probability sampling technique which implies that the sample was chosen for accessibility reasons (Bryman \& Bell, 2007).

${ }^{2}$ As the factor analysis method will be used for processing the data collected through the questionnaire, the sample size must meet the requirements of said method. Researchers are far from unanimous on this point. Indeed, some consider that the size of a sample must be greater than 100, that the size of 200 is considered important, and that 50 represents a minimum threshold required (Boomsma, 1985). In general, the proposed ratios range from an absolute minimum of 5: 1 (5 responses per item) to an absolute maximum of 10: 1 (Kerlinger, 1986). According to MacCallum et al. (1999), a size between 100 and 200 is recommended.
} 
Table 1 Reliability test

\begin{tabular}{lll}
\hline & Number of items & Cronbach's alpha \\
\hline The overall model & 28 & 0,948 \\
Compliance dimension & 4 & 0,815 \\
Assurance dimension & 4 & 0,826 \\
Reliability dimension & 5 & 0,896 \\
Tangibles dimension & 3 & 0,835 \\
Empathy dimension & 4 & 0,761 \\
Responsiveness dimension & 4 & 0,899 \\
Digitalization dimension & 4 & 0,825 \\
\hline
\end{tabular}

Data analysis and results

Descriptive statistics

The descriptive statistics of the 28 service quality items as well as four customer satisfaction measurement items are shown in Table 2. Overall, it seems that Tunisian Islamic banking customers dare not fully satisfied with their banks' services (mean = 3.44). Concerning service quality dimensions, Tunisian Islamic banks are found to be performing best on "tangibles," displaying a mean rating of 4.06. More importantly, the "compliance" dimension exhibits the lowest mean rating (3.45). This would imply that Islamic banking customers in Tunisia lack confidence that their banks are compliant with Islamic banking principles.

\section{Service quality measurement}

Factor analysis was carried out to establish the factor structure of the service quality model relative to the industry and service context under study. Bartlett's test for sphericity was used to test the null hypothesis that the correlation matrix between the 28 items has an identity matrix. The null hypothesis was rejected $\left(x^{2}=2917,128 \mathrm{df}=378\right.$, $p$ - value $=0.000$, Table 3). In the Table 4, The Kaiser Meyer-Olkin measure of sampling adequacy yielded a coefficient of 0.919 which is interpreted as marvelous (Kaiser, 1974). These two tests mean the items have adequate common variance and acceptable factorability (Tabachnick \& Fidell, 1996).

Thus, the 28 items were factor analyzed, producing five oblique factors to retain given that they have eigenvalues greater than one (Kaiser, 1974). Oblique factors were preferred because they rotate to simple structures and agree more with psychological

Table 2 Descriptive statistics

\begin{tabular}{ll}
\hline Variable & Average mean \\
\hline Compliance & 3.45 \\
Assurance & 3.94 \\
Reliability & 3.66 \\
Tangibles & 4.06 \\
Empathy & 3.53 \\
Responsiveness & 3.61 \\
Digitalization & 3.54 \\
Satisfaction & 3.44 \\
\hline
\end{tabular}


Table 3 Bartlett's test

\begin{tabular}{llll}
\hline Bartlett's test & $X^{2}$ & df & $p$ \\
& 2917,128 & 378 & 0.000 \\
\hline
\end{tabular}

theory than do orthogonal factors (Kline, 2000). The five-factor solution accounted for a combined 69.93 percent of the total variance (See Table 5). A total of 28 items were loaded on the factors but two items had to be removed because their factor loadings are less than 0.4 (Floyd \& Widaman, 1995). The reliability of the factors was calculated using Cronbach's alpha. All five factors demonstrate reliability, with Cronbach's alphas all above the required 0.8 cut-offs (Hair, Anderson, \& black, 1998). Factors extracted, along with their labeling and analysis, are discussed hereafter. The first factor is labeled "confidence" and it comprises items from the basic Parasuraman et al.'s (1988) scale regarding the two dimensions of assurance (items 5, 6, 7, and 8) and reliability (items 9, 10, 11, and 12). The "compliance" factor encompasses the need for confidence about the compliance of Islamic banks with Shariah principles (items 1, 2, 3, and 4). We label the third-factor "digitalization," as these items pertain to the ability of the bank to offer digitally empowered experience to its customers (items 25, 26, 27, and 28). Consistent with Parasuraman et al. (1988), the fourth-factor "tangibles" refers to the quality of the intangible aspects and visible attributes of the service (items 14, 15, and 16). The last factor includes items of the responsiveness (items 21, 22, 23, and 24) and the empathy (items 18, 19, and 20) dimensions as proposed by Parasuraman et al. (1988), accordingly, we named it "human skills."

\section{Satisfaction}

The Kaiser Meyer-Olkin measure of sampling adequacy yielded a coefficient of 0.797 which is interpreted as meritorious. The four items used to measure form a single factor accounting for 70.13 percent of the total variance. A Cronbach's alpha of 0.841 establishes reliability for the measure (See Table 6).

Satisfaction is a cognitive evaluation, while loyalty is related to commitment (satisfaction is a necessary but not sufficient condition to loyalty). We note that these four specific items cover both satisfaction and loyalty measures.

\section{Regression analysis}

To study the impact of the service quality factors (the five-factor scores as the independent variables) on the satisfaction of Tunisian Islamic banking customers (the dependent variable), multiple regression analysis was applied. The results of the multiple regression analysis are reported in Table 7.

The service quality dimensions accounted for a significant amount of variance in satisfaction $\left(R^{2}=68.3\right.$, Fisher $=59.91, p$ value $\left.=0.000\right)$. All service quality dimensions tend to be highly correlated with satisfaction, except for tangibles.

The greatest influence on satisfaction is made by "Confidence" $(\beta=0.376, t$ student $=$ 4.850, $p$ value $=0.00)$ and then "Human skills" $(\beta=0.297, t$ student $=4.127, p$ value $=$

Table $4 \mathrm{KMO}$ measure 
Table 5 Factors, factor loadings and reliabilities for quality construct

Extracted factors

1 9: Keeping a promise to do something by a certain time

1 5: The behavior of employees instilling confidence in their customers

I 10: Showing sincere interest in solving a customers' problems

I 8: Employees having the knowledge to answer customers' questions

1 11: Performing the service correct for the first time

I 12: Providing the service at the time the service was promised

1 6: Customers feeling safe in their transactions

1 7: Employees being consistently courteous with their customers

\section{Factor 2: compliance}

I 3: Provision of Islamic products and services

1: Runs in Islamic principles

I 2: No interest paid nor taken on savings and loans

1 4: Provision of profit-sharing investment products

Factor 3: digitalization

I 28: Provision of mobile banking services and apps

| 25: Provision of online services

$2 \quad \begin{array}{llll}\sigma^{2} & \text { Vp } & a\end{array}$

0.767

$45.48 \quad 11.49 \quad 0.923 \quad$ | 13: Insisting on error-free

0.706

0.683

0.678

0.669

0.640

0.620

0.409

$8.29 \quad 2.15 \quad 0.815$

0.935

0.851

0.646

0.507

\section{$\begin{array}{lll}7.3 & 1.89 & 0.825\end{array}$}

0.819

0.790

I 26: Offering electronic payment solutions

0.672

0.494

27: The bank is active on social platforms

\section{Factor 4: tangibles}

| 14: Modern looking equipment

| 15: Visually appealing physical facilities

| 16: Neat-appearing employees

\section{Factor 5: Human skills}

I 22: Employees are never being too busy to respond to customers' requests

I 23: Employees giving prompt service to customers

I 20 Having the customers' best interest at heart 0.550

I 18: Operating hours convenient to all their customers

I 21: Employees always being willing to help customers

I 24: Employees telling customers exactly what 0.506 services will be performed

I 19: The employees understanding the specific $\quad 0.444$ needs of their customers

Deleted items records 
Table 6 Factors, factor loadings, and reliabilities for satisfaction construct

\begin{tabular}{|c|c|c|c|c|c|}
\hline Extracted factor & r & $\sigma^{2}$ & $\mathrm{Vp}$ & a & $\begin{array}{l}\text { Deleted } \\
\text { Items }\end{array}$ \\
\hline Satisfaction & & $\begin{array}{l}70, \\
13\end{array}$ & $\begin{array}{l}2, \\
80\end{array}$ & $\begin{array}{l}0, \\
841\end{array}$ & \\
\hline Did you recommend your bank to your friends and family members? & 0,90 & & & & \\
\hline Your overall satisfaction with your bank's' services? & $\begin{array}{l}0, \\
821\end{array}$ & & & & \\
\hline Did you have the intention to switch to another bank in the future? & $\begin{array}{l}0, \\
716\end{array}$ & & & & \\
\hline $\begin{array}{l}\text { Did you have the intention to purchase other services or products from } \\
\text { your bank? }\end{array}$ & $\begin{array}{l}0, \\
665\end{array}$ & & & & \\
\hline
\end{tabular}

0.00). Hence, the need for a positive personal interaction inspiring trust and engagement is a significant predictor of customer satisfaction in Tunisian Islamic banking. The next strongest contribution is made by "Compliance" $(\beta=0.207, t$ student $=3.895$, $p$ value $=0,00$ ). Accordingly, running on Islamic law principles is of special interest to Islamic banking customers. "Digitalization" is found to have the fourth strongest influence on satisfaction $(\beta=0.190, t$ student $=3.414, p$ value $=0.001)$. Therefore, the results show that digitalization of Islamic banking is in the customers' interest. "Tangibles" makes the smallest contribution $(\beta=-0.029, t$ student $=-0.485, p$ value $=$ 0.628 ) which is not statistically significant. The results provide predictive validity for the model, with examination of the $t$ values indicating that "Human skills," "Confidence," "Compliance," and "Digitalization" contribute to prediction of satisfaction.

\section{Discussion}

In today's digital era, Islamic bank managers need to understand what criteria are being used by customers to evaluate their services as consumer behavior patterns are changing due to the current digital trend. The current research makes important contributions to the field of banking services by identifying the major service evaluation criteria for Islamic banking by Tunisian Customers. The analysis of the 28 items expected to assess the service quality in this study allows us to identify five dimensions of service quality in the case of Tunisian Islamic banking. These dimensions are confidence (reflecting reliability and assurance), compliance, digitalization, human skills (reflecting empathy and responsiveness), and tangibles.

In the previous empirical studies, which employed the SERVQUAL instrument in modified form, a wide variety of service quality structure has been revealed, the number

Table 7 Relationships between service quality factors and satisfaction

\begin{tabular}{lll}
\hline & Beta weights & $\boldsymbol{t}$ student \\
\hline Confidence & $0.376^{* * *}$ & 4.850 \\
Human Skills & $0.297^{* * *}$ & 4.127 \\
Compliance & $0.207^{* * *}$ & 3.895 \\
Digitalization & $0.190^{* * *}$ & 3.414 \\
Tangibles & -0.029 & -0.485 \\
$\boldsymbol{R}^{\mathbf{2}}$ & 0.683 & \\
adjusted $\boldsymbol{R}^{\mathbf{2}}$ & 0.671 \\
Fisher's value & $59.91^{* * *}$ & \\
Notes: Dependent variable: satisfaction. ${ }^{* *}$ Significant $(p<0.05) ;{ }^{* *}$ significant $(p<0.01)$
\end{tabular}


varying according to the examined service sector (Buttle, 1996). Consequently, keeping in mind that the adjusted SERVQUAL instrument was used in a context (the Tunisian Islamic banking sector) different from those investigated by Parasuraman et al. (1991), it seems to be not surprising to identify a distinct standard for banking service quality evaluation.

As expected, the findings of this study prove that providing the best service quality may result in higher satisfaction levels among Tunisian Islamic banking customers. This result goes online with previous research that stated that there was a strong link between service quality and customer satisfaction in Islamic banking (Owen \& Othman, 2001). Although Islamic banking customers are satisfied with the overall service quality provided by their banks, it is not guaranteed that their customers do not switch to other banks. Therefore, Islamic banks need to strengthen their customer relationship management through the enhancement of customers' trust in Shariah compliance. Our results suggest that Islamic banking customers attach great importance to the compliance dimension. The latter may determine the decision-making behavior of pious customers on whether they will continue the relationship with Islamic banks (Hassan \& Lewis, 2007). Although Shariah compliance was well ranked as a determining factor, it was not the most significant factor. This result is in line with those of Hayat and Khuram (2011) who specified that the majority of Islamic banks customers value product features and quality of service as major factors for making a selection of Islamic banks at the expense of religious beliefs. Therefore, Islamic banks need to better examine the drivers of their market identity and must consider service quality as equally important to "Sharia compliance" in designing the marketing strategy of Islamic banking services. The development of valid and distinct measures of service quality according to the upcoming digital customer needs remains one of the most important aspects to make customers, especially with the quick-spreading digital transformation all over the world. Indeed, our results prove that digital banking is a major determinant when it comes to overall customer satisfaction and that Generation Y displays a clear preference for digital channels. That result was not surprising since customers' intentions to use technology are heavily influenced by their attitude towards technology (Gurjeet \& Sangeeta, 2013). Given the fact that Tunisia, and the world, by and large, are becoming increasingly more digitalized, the ease of switching banks will increase customers' expectations (Heffernan, 2005). The challenge for Islamic banks is to adapt their strategy to match Millennials' habits and behaviors who are looking for digital banking offerings matching their lifestyle needs. Be that as it may, some considerations should be taken into account when implementing digital banking. Convenience and security issues play a crucial role (Anthony \& Yamit, 2017; Mbama \& Ezepue, 2018). By 2025, Josh (2014) estimated that Generation Y would represent nearly half of the total active population in the world. Hence, to remain competitive, Islamic banks must thrive to move away from traditional banking to develop products and services that truly reflect the digital transformation of today's young customers' demand. More importantly, the research findings suggest that human-based service delivery is the most relevant customer satisfaction criteria most customers ever have. People still like human interaction and trust people more than technology, even if customers are increasingly interacting with technology. This result goes online with Luiz and Smith (2000) who stated that "bank customers' attitudes towards the human provision of services and subsequent level of 
satisfaction will impact on bank switching more than when the same service delivery is made through automation." Better experiences are not exclusively about better technology. The human resources factor also matters and customers are always in need for a positive personal interaction inspiring trust and engagement (Jabnoun \& Al-Tamimi, 2003). In other words, digital is not an end in itself, but it is serving as a means to reach the organizational objectives of Islamic banks. Consequently, Islamic banks must leverage appropriate technology to develop new digitalized systems but most importantly commit to a new engagement model that focuses on the human touch while matching the customers' level of expectation with the new systems. Finally, "tangibles" are found to have the least impact upon satisfaction which is not significant. In our opinion, "tangibles" are important, but automatically expected by Tunisian Islamic banks customers. Islamic banking is a relatively recent phenomenon in Tunisia, and Islamic banks have mostly new buildings and modern looking equipment. Thus, tangibles may constitute a hygiene factor (Herzberg, 1982), so that it is considered by customers as an expected requirement but leads to no dissatisfaction rather than satisfaction.

\section{Conclusion and recommendations}

A rich stream of literature in the areas of service quality and customer satisfaction has evolved and reproduced over the past two decades. Nevertheless, such studies in Tunisian Islamic banks remain scarce. In this age of digital transformation, Islamic bank managers need to understand what criteria are being used by customers to evaluate their services. This paper highlights the importance of the service quality-adjusted pattern and its potential impact on customer satisfaction of Tunisian Islamic banks. The study proposed that the SERVQUAL dimensions would replicate in the Islamic banking industry but with certain modifications given the foundation philosophy underlying this banking sector. Most importantly, the research proposed that digitalization is an essential determinant of service quality and overall customer satisfaction for today's digital customers. The findings reveal that Islamic banks need to pay attention to the way the services are delivered and not take it for granted that customers are only focusing on compliance. To remain competitive, Islamic banks must update their service quality set to align with the upcoming digital customer needs. However, it is important not to neglect the core role of human-based service delivery in driving engagement, loyalty, and customer satisfaction.

\section{Limitations and future research}

First, further research should be considered to gather more information regarding the impact of the digital transformation on the evaluation of service quality and customers' satisfaction by Islamic vs conventional banks. Second, the study utilized an average convenience sample instead of a random sample. Therefore, it is suggested to enlarge the sample size for better generalization of the findings in other countries. Moreover, although the web-based survey approach has enabled the research to prevent respondents from submitting incomplete questionnaires, which is an advantage, any study based on a predesigned questionnaire suffers from the limitation of dishonesty and differences in understanding and interpretation. Third, although tests for reliability and validity provide initial support for the adopted 
measures, there remains a possibility that not all service quality dimensions are captured. Thus, qualitative interviews with customers are recommended to explore any other aspects that may contribute to the development of a more meaningful measurement of service quality. Fourthly, another limitation concerns the strong assumption adopted for the transformation of Likert scales which give ordinal data into a cardinal scale in order to quantify customer satisfaction. Finally, and to test our model, we can future studies can applicate another original method for Measuring and Implementing Service Quality like the multicriteria method dubbed MUSA (MUlticriteria Satisfaction Analysis) ${ }^{3}$.

\section{Abbreviations}

ATM: Automated Teller Machine; CARTER: Compliance, Assurance, Reliability, Tangibles, Empathy, Responsiveness; EFTPOS: Electronic Fund Transfer at the Point of Sale; GCC: Gulf Cooperation Council; MUSA: MUlticriteria Satisfaction Analysis; SERVQUAL: SERVice QUAlity; UAE: United Arab Emirates

\section{Acknowledgements}

No acknowledgements.

\section{About the authors}

- Ghazi Zouari is an Associate Professor in Finance and Accounting Methods at the Faculty of Economic Sciences and Management of Sfax, University of Sfax, Tunisia. He is a Head of the Management Department, Chairman of the Thesis and Habilitation Research Committee, Responsible for a research team at the Research Laboratory of Information Technologies, Governance, and Entrepreneurship (LARTIGE) at University of Sfax and Official subscription representative of the Publishing house "Virtus Interpress." His domain of expertise is the decision process, organizational architecture, R\&D investment, behavioral finance, Islamic finance, FinTech, and corporate governance.

- Marwa Abdelhedi is a PhD Student in Finance and Accounting Methods at the University of Sfax, Tunisia. Her main research interests are related to corporate governance, Islamic finance, Fintech, and firm value.

\section{Authors' contributions}

Zouari $\mathrm{G}$ and Abdelhedi $\mathrm{M}$ analyzed and interpreted the association between digitalization and compliance, as a service quality dimension, and customer satisfaction. They proposed an extended SERVQUAL model that has five dimensions of service quality, i.e., confidence, compliance, digitalization, tangibles, and human skills and they demonstrate a positive and significant relationship between the main dimensions of service quality and customer satisfaction, except for tangibles. Consequently, Tunisian Islamic banks seeking performance need to pay attention to the way the services are delivered and not take it for granted that customers are only focusing on compliance. Dealing henceforth with Generation Y customers, digital banking must appear among the Islamic bank features to stay relevant in the Digital Era. The authors read and approved the final manuscript.

Funding

None declared under financial, general, and institutional competing interests.

\section{Availability of data and materials}

All data generated or analyzed during this study are included in this published article (and its supplementary information files).

\section{Competing interests}

On behalf of all authors, the corresponding author states that there is no conflict of interest.

Received: 22 April 2020 Accepted: 1 February 2021

Published online: 26 February 2021

\section{References}

Abdullah, A. and Kassim, N. (2009), Measuring perceived quality in Qatari Islamic banks, International Business and Entrepreneurship Development, 4, 1/2, 90-106.

Akhtar, M. N., Hunjra, A. I., Syed Waqar Akbar, S. W., Ur-Rehman, K., \& Niazi, G. S. K. (2011). Relationship between customer satisfaction and service quality of Islamic banks. World Applied Sciences Journal, 13(3), 453-459.

\footnotetext{
${ }^{3}$ The chief objective of MUSA is the development of a model able to evaluate the level of customer satisfaction both globally and partially for each of the characteristics or attributes of the product or service being considered. Furthermore, the method aims at providing an integrated set of results capable of analyzing customer needs and expectations and to justify their satisfaction level. (Grigoroudis \& Siskos, 2010)
} 
Alstad, J. (2002). Use your service edge to your online advantage. American Banker, 167(46), 1-3.

Al-Tamimi, H. A. H., \& Al-Amiri, A. (2003). Analysing service quality in the UAE Islamic banks. Journal of Financial Services Marketing, 8(2), 119-132.

Amin, M., \& Isa, Z. (2008). An examination of the relationship between service quality perception and customer satisfaction: A SEM approach towards Malaysian Islamic banking. International Journal of Islamic and Middle Eastern Finance and Management, 1(3), 191-209.

Anthony, L., \& Yamit, V. (2017). Building customer loyalty in digital banking: A study of bank staffs perspectives on the challenges of digital CRM and loyalty. International Journal of Bank Marketing, 35(6), 858-877. https://doi.org/10.1108/JBM-08-2016-0112.

Babakus, E., \& Boller, G. W. (1992). An empirical assessment of the SERVQUAL scale. Journal of Business Research, 24, $253-268$. https://doi.org/10.1016/0148-2963(92)90022-4.

Barras, R. (1990). Interactive innovation in financial and business services: The vanguard of the service revolution. Research Policy, 19, 215-237.

Bearden, W. O., \& Teel, J. E. (1983). Selected determinants of consumer satisfaction and complaint reports. Journal of Marketing Research, 20, 21-28.

Boomsma, A. (1985). Nonconvergence, improper solutions, and starting values in LISREL maximum likelihood estimation. Psychometrika, 50(2), 229-242.

Boulila, T. N., \& Ben Slama, Z. S. (2014). Tunisia Islamic finance: Overview and future prospects. Journal of Islamic Accounting and Business Research, 5(1), 2-14.

Bryman, A., \& Bell, E. (2007). Business research methods, (2nd ed., ). New York: Oxford University Press Inc.

Buttle, F. (1996). SERVQUAL: Review, critique, research agenda. European Journal of Marketing, 30(1), 8-32.

Carman, J. M. (1990). Consumer perceptions of service quality: An assessment of the SERVQUAL dimensions. Journal of Retailing, 66(2), 33-55.

Castells, M. (2009). Rise of the network society. Malden: Wiley-Blackwell.

Cooil, B., Keiningham, T. L., Aksoy, L., \& Hsu, M. (2007). A longitudinal analysis of customer satisfaction and share of wallet: Investigating the moderating effect of customer characteristics. Journal of Marketing, 71, 67-83.

Cronin, J., \& Taylor, S. (1992). Measuring service quality: A re-examination and extension. Journal of Marketing, 56(3), 55-68.

Dabholkar, P. A., Thorpe, D. I., \& Rentz, J. O. (1996). A measure of service quality for retail stores: Scale development and validation. Journal of the Academy of Marketing Science, 24, 3-16.

Dabholker, P. A. (1996). Consumer evaluations of new technology based self-service options: An investigation of alternative models of service quality. International Journal of Research in Marketing, 3(1), $29-51$.

Dispensa, G. (1997). Use logistic regression with customer satisfaction data, Marketing News. :13.

Dootson, P., Beatson, A., \& Drennan, J. (2016). Financial institutions using social media - Do consumers perceive value? International Journal of Bank Marketing, 34(1), 9-36.

Dusuki, A. W., \& Abdullah, N. I. (2006). Why do Malaysian customers patronize Islamic banks? International Journal of Bank Marketing, 25(3), 142-160.

Ernst, \& Young (2016). World Islamic banking competitiveness report 2016 Available at : https://ceif.iba.edu.pk/pdf/EY-Worldlsla micBankingCompetitivenessReport2016.pdf.

Fakhfakh, H., Zouari, G., \& Zouari-Hadiji, R. (2012). Internal capital markets and investment decisions, corporate governance. The International Journal of Business in Society, 12(2), 179-198.

Floyd, \& Widaman, K. (1995). Factor analysis and development and refinement of clinical assessment instruments. Psychological Assessment, 7, 286-299.

Gallup (2014), Islamic banking remains niche market in North Africa, on the future of Islamic banks in North Africa, A Survey Conducted by in Collaboration on Behalf of the World Bank, January, Available at: www.gallup.com/poll/166583/islamicbanking-remainsniche-market-north-africa.aspx

Ganguli, S., \& Roy, S. K. (2011). Generic technology-based service quality dimensions in banking impact on customer satisfaction and loyalty. International Journal of Bank Marketing, 29(2), 168-189.

Grigoroudis, E., \& Siskos, Y. (2010). Customer satisfaction evaluation: methods for measuring and implementing service quality. 1st ed. International Series in Operations Research \& Management Science, Vol. 139. Springer Science \& Business Media.

Gronroos, C. (1983). Strategic management and marketing in the service sector. Cambridge: Marketing Science Institute.

Gurjeet, K. S., \& Sangeeta, G. (2013). Predicting customers' behavioral intentions toward ATM services. Journal of Indian Business Research, 5(4), 251-270.

Hafsa, Z. O. (2013). Survey on customer related studies in Islamic banking. Journal of Islamic Marketing, 4(3), 294-305.

Hair, J. E., Anderson, R. L. T., \& black, W. C. (1998). Multivariate data analysis, (7th ed., ) Pearson New International Edition, USA.

Hassan, M. K., \& Lewis, M. K. (2007). Product development and Shariah issues in Islamic finance. Thunderbird International Business Review, 9, 281-284.

Hayat, M. A., \& Khuram, S. B. (2011). Customer's criteria for selecting an Islamic bank: Evidence from Pakistan. Journal of Islamic Marketing, 2(1), 14-27.

Heffernan, S. (2005). Modern banking. Chichester: Wiley.

Herington, C., \& Weaven, S. (2009). E-retailing by banks: E-service quality and its importance to customer satisfaction. European Journal of Marketing, 43(9/10), 1220-1231.

Herzberg, F. (1982). The managerial choice: To be efficient and to be human, revised edition. Salt Lake City: Olympus.

Hoffman, K. D., \& Bateson, J. E. (2001). Essentials of services marketing: concepts, strategies and cases. South-Western College Pub.

Isaac, W. K. (2011). Student evaluation of e-service quality criteria in Uganda: The case of automatic teller machines. International Journal of Emerging Markets, 6(3), 200-216.

Jabnoun, N., \& Al-Tamimi, H. (2003). Measuring perceived service quality at UAE commercial banks. International Journal of Commerce and Management, 13(2), 29-53.

Jahanshahi, A. A., Gashti, M. A. H., Mirdamadi, S. A., Nawaser, K., \& Khaksar, S. M. S. (2011). Study the effects of customer service and product quality on customer satisfaction and loyalty. International Journal of Humanities and Social Science, 1(7), 253-260. 
Janahi, M. A., \& Almubarak, M. (2017). The impact of customer service quality on customer satisfaction in Islamic banking. Journal of Islamic Marketing, 8(4), 595-604.

Josh, Z. (2014). How to tell if a 'fact' about millennials isn't actually a fact, the wall street journal 27 November, https://blogs.wsj. com/economics/2014/11/27/how-to-tell-if-a-fact-about-millennials-isnt-actually-a-fact/.

Kaiser, H. F. (1974). An index of factorial simplicity. Psychometrika, 39, 31-36.

Kerlinger, F. N. (1986). Foundations of behavioral research, (3rd ed., ). Philadelphia: Harcourt Brace College Publishers.

Khan, F. (2010). How "Islamic" is Islamic banking? Journal of Economic Behaviour and Organization, 76, 805-820.

Kline, P. (2000). Handbook of psychological testing, (2nd ed., ). London: Routledge.

Kumar, V., \& Reinartz, W. J. (2006). Customer relationship management: a databased approach. Hoboken: Wiley.

Luiz, M., \& Smith, A. (2000). Modelling bank customer satisfaction through mediation of attitudes towards human and automated banking. International Journal of Bank Marketing, 18(3), 124-134.

MacCallum, R. C., Widaman, K. F., Zhang, S., \& Hong, S. (1999). Sample size in factor analysis. Psychological Methods, 4(1), 8499.

Manrai, L. A., \& Manrai, A. K. (2007). A field study of customers' switching behaviour for bank services. Journal of Retailing and Consumer Services, 14, 208-215.

Martins, C., Oliveira, T., \& Popovic, A. (2014). Understanding the internet banking adoption: A unified theory of acceptance and use of technology and perceived risk application. International Journal of Information Management, 34(1), 1-13.

Mbama, C. I., \& Ezepue, O. P. (2018). Digital banking, customer experience and bank financial performance: UK customers' perceptions. International Journal of Bank Marketing, 36(2), 230-255. https://doi.org/10.1108/IJBM-11-2016-0181.

Metawa, S. A., \& Almossawi, M. (1998). Banking behaviour of Islamic bank customer's: Perspectives and implications. International Journal of Bank Marketing, 16(7), 299-313.

Munusamy, J., Chelliah, S., \& Hor, W. M. (2010). Service quality delivery and its impact on customer satisfaction in the banking sector in Malaysia. International Journal of Innovation, Management and Technology, 1(4), 398-403.

Muslim, A., Zaidi, I., \& Rodrigue, F. (2013). Islamic banks: Contrasting the drivers of customer satisfaction on image, trust, and loyalty of Muslim and non-Muslim customers in Malaysia. International Journal of Bank Marketing, 31(2), $79-97$.

Naser, K., Jamal, A., \& Al-Khatib, K. (1999). Islamic banking: A study of customer satisfaction and preferences in Jordan, international J. Bank Marketing, 17(3), 135-150.

Nunnally, J. C., \& Bernstein, I. H. (1994). The assessment of reliability. In Psychometric theory, (3rd ed., pp. 248-292). New York: McGrawHill.

Osman, I., Ali, H., Zainuddin, A., Rashid, W. E. W., \& Jusoff, K. (2009). Customers satisfaction in Malaysian Islamic banking. International Journal of Economics and Finance, 1(1), 197-202.

Owen, L., \& Othman, A. (2001). Adopting and measuring customer service quality (SQ) in Islamic banks: A case study in Kuwait finance house. International Journal of Islamic Financial Services, 3(1), 1-26.

Parasuraman, A., Zeithaml, V. A., \& Berry, L. L. (1985). A conceptual model of service quality and its implication for future research. Journal of Marketing, 49(4), 41-50.

Parasuraman, A., Zeithaml, V. A., \& Berry, L. L. (1988). SERVQUAL: A multiple-item scale for measuring consumer perceptions of service quality. Journal of Retailing, 64(1), 12-40.

Parasuraman, A., Zeithaml, V. A., \& Berry, L. L. (1991). Refinement and reassessment of the SERVQUAL scale. Journal of Retailing, 67(4), 420-450.

Prensky, M. (2001). Digital natives, digital immigrants, part 1. On the Horizon, 9(6), 1-6.

Reichheld, F. F., \& Sasser Jr., W. E. (1990). Zero defections: Quality comes to services. Harvard Business Review, 68(5), 105-111.

Saleem, M. A., Zahra, S., Ahmad, R., \& Ismail, H. (2016). Predictors of customer loyalty in the Pakistani banking industry: A moderated-mediation study. International Journal of Bank Marketing, 34(3), 411-430.

Solomon, M. (1996). Consumer behavior, (2nd ed., p. 346). Boston: Allyn and Bacon.

Sreejesh, S., Anusree, M. R., \& Mitra, A. (2016). Effect of information content and form on customers' attitude and transaction intention in mobile banking: Moderating role of perceived privacy concern. International Journal of Bank Marketing, 34(7), 1092-1113.

Tabachnick, B. G., \& Fidell, L. S. (1996). Using multivariate statistics, (3rd ed., ). New York: Harper Collins.

Urban, J. D., \& Pratt, D. M. (2000). Perception of banking services in the wake of banking mergers: An empirical study. Journal of Services Marketing, 14(2), 118-131.

Veysel, Y., Erkan, A., \& Hüseyin, G. (2018). Investigating the relationship between service quality dimensions, customer satisfaction and loyalty in Turkish banking sector: An application of structural equation model. International Journal of Bank Marketing, 36(3), 423-440.

Wilson, R. (2011), Islamic banking and finance in North Africa: past development and future potential. Report by African Development Bank. https://www.afdb.org/en/news-and-events/islamic-banking-and-finance-in-north-africa-8436.

Yavas, U., Bigin, Z., \& Shenwell, D. (1997). Service quality in the banking sector in an emerging economy: A consumer survey international journal of banking. Marketing, 15(6), 217-223.

Zaher, T. S., \& Hassan, M. K. (2001). A comparative literature survey of Islamic banking and finance, financial markets. Institutions and Instruments, 10(4), 155-199.

Zouari, G. (2008). L'architecture organisationnelle et la décision d'investissement: Le cas tunisien, Thèse de Doctorat en sciences de Gestion (finance). Dijon: Université de Bourgogne, Janvier.

Zouari, G. (2011). Specific knowledge, investment decision and organizational architecture. Journal of Research in International Business and Management, 1(3), 49-61.

Zouari-Hadiji, R. (2010). Modes de gouvernance et Investissement en R\&D : Une perspective de comparaison international, Thèse de Doctorat en Méthodes de finance et Comptabilité (option finance). FSEG Sfax: Université de Sfax, Décembre.

\section{Publisher's Note}

Springer Nature remains neutral with regard to jurisdictional claims in published maps and institutional affiliations. 